\title{
The importance of Biotechnology in the health area: historical overview and future perspectives
}

\author{
Jhonatan Miguel Silva', Antonio Carlos Massabni² \\ ${ }^{*}$ Corresponding author: E-mail address: jhonatanmiguelsilva1@gmail.com
}

Abstract: Biotechnology, in a broad sense, comprises the manipulation of microorganisms, plants and animals, with the proposal to obtain processes and products of interest to society. Although the term appeared at the beginning of the 20th century, biotechnological processes have been present since ancient times in the production of fermented food and beverages. Biotechnology has also been present since the beginning of Medicine. Inhaling powder from sun-dried human smallpox wounds or using secretion of the udders of cows contaminated with bovine smallpox are examples of ancient techniques used as methods of immunization of the disease. In this sense, many treatments have emerged over time, such as vaccines, the production of penicillin, the first antibiotic and the production of insulin by recombinant DNA, which have revolutionized Medicine and enabled a better quality of life for humans. Many products and materials from Biotechnology are still emerging, such as scaffolds in Regenerative Medicine for bone tissue recovery, bacterial cellulose tubes used as artificial blood vessels, induced pluripotent stem cells and microphysiological systems, which promise to further improve modern Medicine and provide better techniques and therapies for various treatments.

Keywords: Biotechnology; Vaccines; Scaffolds; Regenerative Medicine.

\section{Introduction}

Biotechnology, a word derived from the Greek bios (ßioc) life; technos

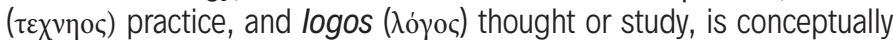
recognized as the union of Biology and Technology. However, there is no consensus about its definition and various ways of defining it can be found. According to Faleiro and Andrade," "in its broader meaning, Biotechnology is defined as the use of living beings, their parts or products for the production of goods and services". According to the Brazilian Ministry of the Environment, ${ }^{2}$ "Biotechnologies, in its broadest sense, include manipulation of microorganisms, plants and animals, with a view to obtaining processes and products of interest to society".

There is also a discussion on what is meant by classical and modern biotechnology. According to Brazilian Ministry of Industry, Foreign Trade and Services, ${ }^{3}$ classical Biotechnology refers to traditional processes such as fermentation, genetic improvement by selection, the use of living beings or their parts to produce goods and services. Modern Biotechnology, according to Faleiro and Andrade ${ }^{1}$ started with the discovery of DNA that enabled a revolution in the areas of Genetics and Molecular Biology.

Although the term Biotechnology appeared at the beginning of the 20th century, the techniques of classical Biotechnology have been used for quite some time. It is estimated that fermentation processes for the production of food such as cheese and wine date back to $6000 \mathrm{BC}$ by the Assyrians and Babylonians. 1,4-6

Classical Biotechnology techniques were also used in antiquity for therapeutic purposes. The Chinese practice of inhaling dust from sundried smallpox wounds and the use of bovine smallpox wound secretions to prevent human smallpox are good examples of these techniques. ${ }^{7,8}$

\section{Objectives}

The objectives of the present work focus on presenting a brief historical overview of the contributions of Biotechnology to human health and pointing out some future perspectives that may further improve Medicine and possibly provide new technologies and therapies for various treatments.

\section{Methodology}

A brief bibliographic survey was conducted in databases, books and scientific articles related to Biotechnology, its definitions and applications in the area of Medicine. In addition, numerical and statistical data cited in the present study were taken from sources and reports of national and international entities, as well as from scientific articles and websites present in the literature.

\section{Literature Review}

\section{Variolation And The Origin Of Vaccines}

The history of the emergence of vaccines is directly related to a very old disease, today practically eradicated: smallpox. There are ancient Egyptian, Indian and Chinese writings that already described the symptoms of the disease. In 1898 the mummy of Pharaoh Ramses $V$ was discovered (dated $1157 \mathrm{BC}$ ) with signs of skin eruptions quite characteristic of people with this disease. ${ }^{9}$ Smallpox was responsible for the death of millions of people around the world. It is estimated that the disease prevailed in China and India around 1000 BC. However, the first recorded epidemic occurred in Arabia during the sixth century. The disease is believed to have spread throughout North Africa and Europe during the sixth, seventh and eighth centuries ${ }^{9}$ as a result of Arab invasions. According to Behbehani, ${ }^{9}$ the disease was reintroduced in Europe due to the Crusades, which occurred between the years 1096 and 1291, and stayed there. During the 18th century, smallpox was estimated to have been responsible for the deaths of approximately 400,000 people a year in Europe and caused about a third of all blindness on the continent.

Variolation was one of the first techniques of smallpox immunization. The method was practiced in different ways by different people. However, in short, the practice consisted of the same principles, which promoted the contact of healthy people with parts of wounds or pustules

PhD student of the Graduate Program in Biotechnology, Regenerative Medicine and Medicinal Chemistry of University of Araraquara (Uniara).

2 Professor of the Graduate Program in Biotechnology, Regenerative Medicine and Medicinal Chemistry of University of Araraquara (Uniara). 
of contaminated people in the hope of developing a milder form of the disease, and so becoming immune. ${ }^{10}$ More than 500 years ago in China, sun-dried smallpox wounds were used to prevent the disease. The method was based on the exposure of pathogens to solar radiation that weakened them. Thus, when inhaling the powder obtained, the body would come into contact with a more harmless version of the virus and

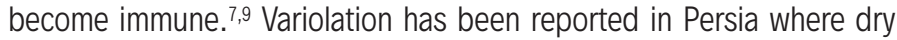
pustules powder was taken as a form of immunization. In Greece, Turkey, Arabia, North Africa and the Caspian Sea region, the practice consisted of rubbing pustules from wounds on the scratched skin of children. ${ }^{9}$

It was only after the emergence of a safer and more efficient method of smallpox prevention that variolation was left aside. During his studies, around 1780, Edward Jenner observed that bovine smallpox could immunize people from the human version of the disease. According to Behbehani, ${ }^{9}$ Jenner heard from a dairy patient who treated pustular wounds on her skin that her disease, although similar, could not be smallpox because she had already been contaminated with bovine smallpox. This was a very popular knowledge among local farmers. Thus, Edward Jenner discovered, by performing several tests, the efficiency of using wound secretions present in udders of cows contaminated with a specific type of bovine smallpox (because he observed other variations attributed to the same disease in cattle) in the immunization of human smallpox. Therefore, he developed a method very similar to variolation, but using secretions from cows, and the first vaccine appeared, a term derived from the Latin vaccinus which means "derived from the cow". $9,11,12$

During the 19th century, vaccination against smallpox became a worldwide practice, especially in Europe and North America, but the principles learned from Jenner's results remained dormant for more than a century and a half, during which no new vaccines appeared. Despite being shown to be effective in immunization, Jenner's vaccine suffered protests and objections from the population and the church, as the possibility of death of the inoculated was recognized (from two to three deaths out of every 100 inoculated individuals). In addition, there was the fear on part of the population that this operation consisting in the introduction of material extracted from cows would transfer bovine characteristics, such as bovine features, birth of horns and mooing, to the "vaccinated". Thus, it was necessary to increase the reliability of vaccines and eliminate the idea that diseases would be "divine punishment". 11,13,14 Figure 1 shows a James Gillray's cartoon drawn at 1802 which demonstrates the population's concern about Jenner's vaccines. ${ }^{15}$

Much of this disbelief was due to ignorance of the cause of the diseases. Even at that time, experiments were being conducted to obtain

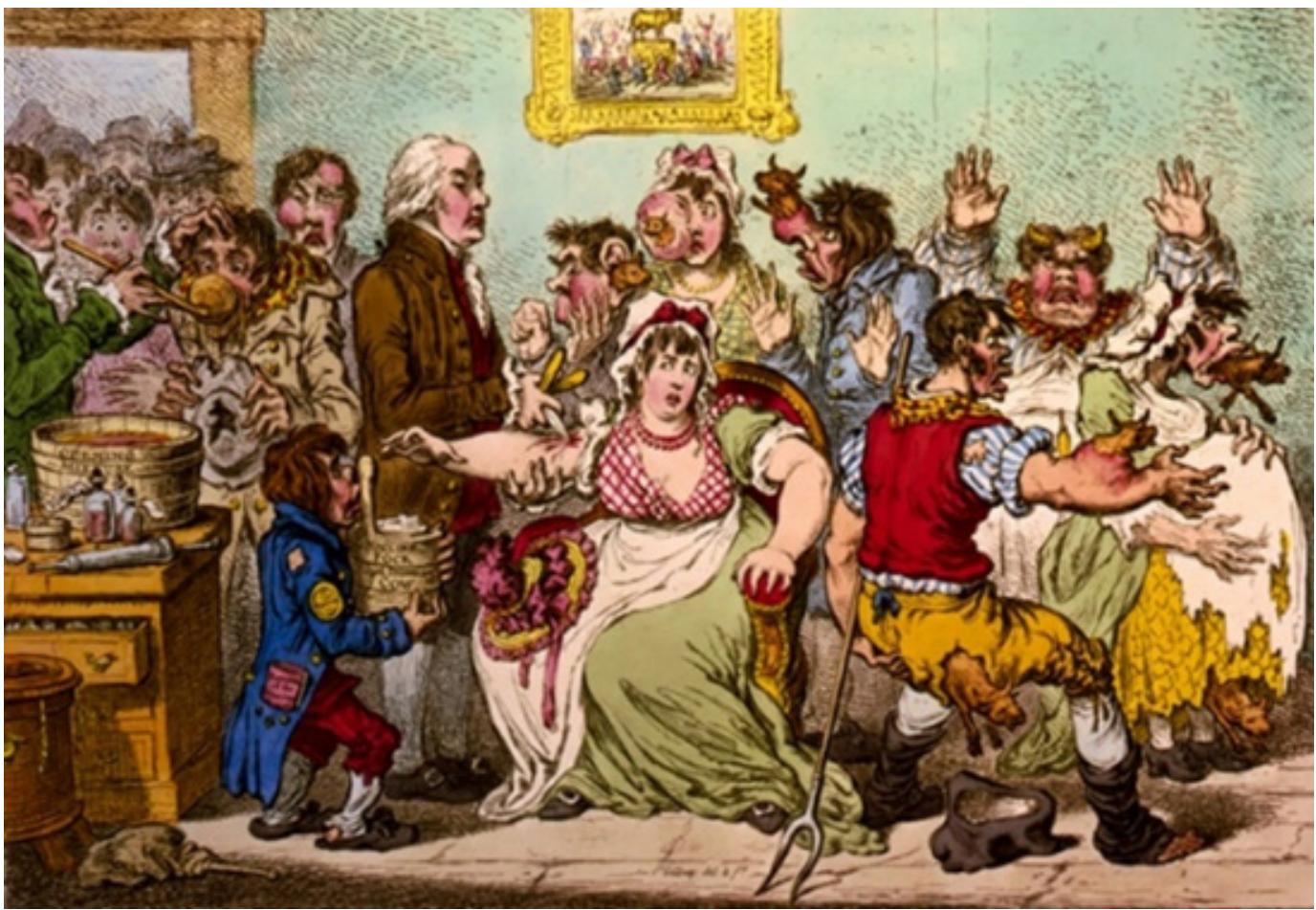

Figure 1 - English charge from the 19th century showing people acquiring bovine characteristics after immunization. Source: The British Museum ${ }^{15}$. Image in the public domain.

evidence that would discredit the theory of spontaneous generation in favor of the germinal theory of the disease. Louis Pasteur and Robert Koch, however, developed research that could prove that infectious diseases were caused by microorganisms. 11,13,14,16

Pasteur, by studying the metabolism of microorganisms, has discovered ways of transforming pathogens to produce vaccines and other new ways of preventing and treating infections. Thus, techniques such as the attenuation or inactivation of pathogens that enabled the immunization of several diseases, such as rabies, typhoid fever, cholera and black plague (bubonic plague) ${ }^{13}$ have emerged.

\section{Penicillin discovery}

Another great contribution of Biotechnology to modern Medicine is the production of penicillin, the first antibiotic. The world's population, especially in Europe and Asia, has suffered several cases of pandem- ic in the pre-antibiotic era. It is estimated that the black plague alone, caused by the bacteria Yersinia pestis, was responsible for at least three pandemics in history, causing almost 100 million deaths in Europe and the outbreak between 1895 and 1930, with about 12 million victims, mainly in India. ${ }^{16}$

For thousands of years, when nothing was known about the cause of infections, prevention methods, antibiotics, and vaccination, mankind was tortured by massive epidemics such as syphilis, smallpox, malaria, typhoid, yellow fever, leprosy, tuberculosis, Spanish flu, cholera, and black plague, to name only a few examples. ${ }^{16}$

The accidental discovery of penicillin in 1928 by the English physician Alexander Fleming ${ }^{17}$ inaugurated a new era in Medicine, since infectious diseases that would normally lead to death could be cured. Penicillin is a substance secreted by the fungus Pennicilium and has proven to be more efficient in controlling bacterial proliferation compared to chemical 


\section{H. Souza, A. C. Massabni}

substances used at the time, such as salvarsan (used in the treatment of syphilis), proflavine (widely used in World War II, mainly in deep wounds) and sulfas or sulfonamides (prontosil). ${ }^{18}$ However, the antibiotic was only introduced as a therapeutic agent in the 1940s. After the process of industrialization of penicillin, especially as a consequence of World War II, a rapid growth was observed in the discovery and development of new antibiotics. $^{18}$

\section{Diabetes and the production of human insulin by recombi- nant DNA}

The production of synthetic insulin by transgenic microorganisms was also a major milestone in biotechnology in the field of Medicine for the treatment of diabetes. Diabetes mellitus is a very old disease. There are records of his symptoms dating from $1500 \mathrm{BC}$, such as frequent and abundant diuresis, uncontrollable thirst and marked weight loss as its main clinical manifestations. Aretaeus, a Roman physician, created the term diabetes which means "going through" because of excessive diuresis, one of its most evident symptoms. 19,20

It was only in 1889 that Joseph von Mering and Oskar Minkowsky, during their research on fat digestion, observed that removing the pancreas from dogs triggered very similar symptoms of the disease. In 1908, the scientist Georg Zuelzer developed the first injectable pancreatic extract that suppressed glycosuria, but this therapeutic modality did not evolve due to its adverse effects. ${ }^{19,20}$

Insulin was isolated from pancreatic extract in 1921 by Frederick Banting and Charles Best in the laboratory of physiologist John Macleod. The first test for decreased glycosuria and ketonuria was performed in 1922 by injecting $15 \mathrm{~mL}$ of pancreatic extract in a 14-year-old patient. However, the effect obtained was lower than expected, in addition to causing abscesses at the place of application. Only after purification of the extract by biochemist James Bertram Collip, which had the desired effect immediately. The discovery of the relationship between pancreatic secretion and diabetes mellitus earned the Nobel in Medicine and Physiology due to this therapeutic achievement. ${ }^{19,20}$

The first commercially produced insulin, the regular insulin or insulin $\mathrm{R}$, extracted from animals, has a rapid mechanism of action, which required several applications throughout the day yielding several complaints from patients. Thus, other types of insulins with longer action time were produced, such as NPH insulin (neutral protamine Hagedorn), with addition of protamine basic protein, and PZI insulin (protamine zinc insulin) with addition of zinc in its composition. However, in clinical practice, different complications of the use of these insulins were observed, such as allergic conditions, lipodystrophy at the sites of application and, most importantly, immunological resistance to insulin. ${ }^{19,20}$

With the advancement of Molecular Biology, the era of human biosynthetic insulins began. Its principle is based on the genetic modification of bacteria to induce the production of the hormone used in the treatment of diabetes. The technique has five general procedures: to fractionate the DNA in specific locations using restriction enzymes; to unite DNA fragments in a covalent way (DNA ligase); to select a DNA for cloning vector, that is, that can self-replicate; to transfer the DNA to a host cell; and to select the cells with the recombinant DNA. The bacteria Escherichia coli was the first organism used for rDNA work and is still the most common host cell. ${ }^{21}$

\section{Biotechnology perspectives for the medicine of the future Regenerative Medicine}

With the development of techniques and new biotechnological materials, the prospects for health are very promising. In particular, the use of bacterial cellulose in the production of scaffolds (threedimensional matrices for cell growth) with potential application in Regenerative Medicine stands out.

Regenerative Medicine is a branch of Medicine that proposes to restore or replace cells, tissues and organs to recover their functionality. According to Porcellini, ${ }^{22}$ it is a very recent area, it appeared in 1997 when Whitman et al. ${ }^{23}$ proposed the integration of platelet-rich plasma adhered to fibrin for possible maxillary bone regeneration. One year later, Marx et al. ${ }^{24}$ there was also a greater bone density in grafts in which platelet-rich plasma was added $(74.0 \% \pm 11 \%$ demonstrated that platelet rich plasma is capable of inducing mandibular bone regeneration. ${ }^{24}$

Bone regeneration consists of the treatment of conditions such as trauma, osteosarcoma (primary bone tumor), osteomyelitis (severe infection of bone tissue) and osteitis (inflammation of bone tissue), and has been a major challenge in surgical practice. Many therapeutic approaches such as allografts (transplantation between different individuals of the same species), xenografts (surgical transplantation between individuals of different species), autografts (transplantation taken from the individual himself) and artificial grafts have been employed to restore bone function. However, such approaches have limitations, such as the low amount of bones donated or removed from the patient, risk of immune system response, possible infections and death of tissues that hinder their application. In addition, synthetic prostheses are hardly capable of mimicking true bones and interacting well with surrounding bone tissues, which can cause some fatigue. ${ }^{25}$ Therefore, Biotechnology applied to bone regeneration has proven to be very promising, especially scaffolds in Tissue Engineering. The scaffolds can promote different types of mechanisms for bone regeneration such as osteoconduction (ability to stimulate the growth of new tissues on the surface and pores of the implant, promoting adherence and proliferation of cells to form new vascularized bone tissue), osteoinduction (ability to attract immature cells and induce them to transform into bone tissue forming cells; in general, induce cells to bone formation in ectopic medium by biomolecular signaling mechanisms) and osseointegration (integration between bone tissue cells and the implant occurs by adhesion of cells on the surface of the implanted material). ${ }^{25}$

The bone has a very complex biomechanical system, which requires from the scaffolds specific properties that to promote this restoration such as biocompatibility, mechanical properties similar to bone structure, adequate porosity that allows the vascularization of bone tissue (between 200 and $350 \mathrm{um}$ ) and bioabsorbability/biodegradability. Thus, scaffolds that use bacterial cellulose have shown to be very promising for bone regeneration, since they have the ideal properties required for such application. ${ }^{25}$

Torgbo and Sukyai's review paper ${ }^{25}$ cites several materials based on bacterial cellulose with potential application in bone regeneration, such as a Huang et al. work, ${ }^{26}$ which produced a scaffold bacterial cellulose/hydroxyapatite agarose gel that was able to promote adhesion, proliferation and cell viability in the osteogenic process of human bone marrow stem cells.

Another area of Regenerative Medicine that will benefit from new biotechnological materials is the production of artificial blood vessels. According to data from the World Health Organization (WHO), cardiovascular disease is the leading cause of mortality worldwide. It is estimated that in 2016 alone they caused the death of approximately 17.9 million people worldwide, about $30 \%$ of all deaths. ${ }^{27}$ According to the study and Lee and Park, ${ }^{28}$ about 600 thousand surgical procedures are performed worldwide every year.

Such a demand, according to Schumann et al., ${ }^{29}$ caused the widespread use of artificial grafts with those of polyethylene terephthalate and expanded polytetrafluoroethylene (PTFE). However, in small diameter grafts $(<6 \mathrm{~mm}$ ) the occlusion rate and consequent thrombosis was $40 \%$ of the cases in less than six months of implantation. The occlusion of artificial vessels is associated with blood interactions with synthetic materials that cause obstruction. In addition, artificial materials increase the risk of bacterial infections and can cause widespread rejections and inflammation.

Considering the natural grafts, implants have been performed using the saphenous vein in revascularization processes, such as the internal mammary vein in autologous graft. However, the procedure is not totally adequate, since, because it is small, the graft may present varicosity. Thus, the search for new implants of small diameter, biocompatible and 
in which inclusion does not occur is of great importance.

Bacterial cellulose presents characteristics such as mechanical properties (Young $134 \mathrm{GPa}$ module and tensile strength of $2 \mathrm{GPa}$ per fiber), high purity, microstructure that allows the adhesion and proliferation of cells and biocompatibility relevant for the production of artificial blood vessels.

The work of Schumann et al..$^{29}$ proposes bacterial cellulose blood vessel transplants in vivo as a replacement for carotid arteries in five rats, with a $1 \mathrm{~mm}$ inner cavity, which were allowed to grow for one year. They were also implanted in eight pigs, weighing between $35-40 \mathrm{~kg}$, in which they were administered in carotid arteries that had free access to food and were allowed to grow for three months. The animals were sacrificed and the implants were evaluated for resistance to blood pressure of 70 $\mathrm{mmHg}$ and vessel obstruction.

In the rats, it was observed that at the contact site between the prosthesis and the newly formed blood vessel, the presence of active fibroblasts that produce collagen, necessary for the integration and adequacy of synthetic vessels to the body of the animal, was verified. Furthermore, in all one-year-old animals, there was no obstruction of any synthetic artery. It is estimated that the high permeability rate may be favored by the targeted nature of BASYC fibers, which facilitate blood flow.

In pigs, on the other hand, the rate of permeability of the grafts was $87.5 \%$ ( 1 out of 8 grafts was found obstructed). It is believed that the obstruction may have occurred due to the circundant tissue that did not adhere correctly to the graft. However, no type of narrowing of the artificial arteries (stenosis) and no type of anastomosis (network of channels that bifurcate) were identified. It is also noteworthy that there were no apparent changes in any of the grafts, including dilation (aneurysm), dehiscence (natural fissure) and fistulas (inappropriate connections of distinct tissues and organs).

\section{Induced pluripotent stem cells}

Modern biotechnology techniques are also emerging and have great potential for various areas of Medicine. One such procedure is the production of induced pluripotent stem cells (iPSC).

The interest in pluripotent cells consists in the treatment of tissues, organs injured or destroyed, so they can be a route for the treatment of Parkinson's disease, spinal cord injuries and diabetes. ${ }^{31}$

Currently, stem cell treatments suffer a major ethical impact from the use of human embryos in the process. Moreover, there is a concern that immunological rejection could occur in treatments. Stem cells can be classified into two main types: embryonic and nonembryonic. Embryonic stem cells have the characteristic of being pluripotent, that is, they can form any type of cell in the three germ layers (endoderm, mesoderm and ectoderm), while nonembryonic stem cells are capable of forming several types of tissues, that is, they are multipotent and can be extracted from some tissues or organs such as the placenta, umbilical cord, bone marrow, peripheral blood.

Initially obtained in the work of Takahashi and Yamanaka ${ }^{30}$ using cultures of embryonic and adult fibroblasts of mouse, iPSCs were produced in vitro by gene reprogramming of somatic cells through four transcription factors that induce them to acquire properties similar to embryonic stem cells. The hypothesis was based on nuclear reprogramming based on oocyte genes (oocytes II), which maintain embryonic pluripotent property for a long time. Through retroviral vectors, exogenous genes are introduced into somatic cells and induce endogenous expression of pluripotency. In addition, exogenous factors that have key roles in cell differentiation are silenced and the pluripotent state becomes completely dependent on the endogenous transcriptional circuit. 30,31

The induced pluripotent stem cells produced in the work of Takahashi and Yamanaka ${ }^{30}$ were subcutaneously transplanted in immunodeficient mice; tumors with cells of the three types of embryonic tissues were found, indicating that the induction of somatic cells to obtain pluripotent properties was effective. The work won the authors a Nobel Prize.
According to Reis et al., ${ }^{31}$ gene reprogramming has been performed using human skin fibroblasts with the use of viral vectors. However, due to the difficulty in obtaining epithelial tissue due to the need for biopsy, some recent studies indicate that other human cells are being used for the production of iPSC, such as adipose tissue stem cells, hepatocytes, peripheral blood lymphocytes, among others, which can enable various treatments and avoid rejection reactions by using the patient's own cells. ${ }^{33}$

\section{Microphysiological systems}

Still thinking aboutiPSC applicationsand the use of 3D supportsforcell culture (scaffolds), the work of Edington et al. ${ }^{33}$ addresses the production of microphysiological systems (MPSs) that mimic physiological functions in vivo through specialized culture microenvironments to perform drug testing in vitro.

Known as "human body in chip" or "organs in tablets", the microphysiological systems are microenvironments of specialized cell cultures, which in 3D matrices (scaffolds) interconnected by microperfusion channels seek to simulate the physiological functioning of the human body. They are being developed to supply the demand in pre-clinical pharmacology for more effective models for toxicity testing and drug safety. Currently, animal models used delay the development of treatments and are not very safe in predicting the safety and efficacy of drugs in humans, causing billions of dollars lost each year. ${ }^{33}$

However, the production of multifunctional microphysiological systems is still under development and presents some technical challenges to be overcome, as described by Edington et al.:33

(i) creation and maintenance of MPSs that exhibit sufficiently representative and robust physiological function in periods of prolonged culture, typically requiring intensive procurement and preparation of primary cells or pluripotent stem cells (PSCs) to achieve functional maturity in specialized microenvironments;

(ii) Design and manufacture of platform-shaped equipment that can accommodate and sustain the relevant MPS - including off-platform transfer to the platform in the case of MPS requiring disparate maturation times and complex means of maturation - by fluidically linking them in a manner that is permissive to quantitative analysis of biological phenomena involving the fate of drugs or disease phenomena; (iii) selection of an average composition compatible with the different MPS on the platform;

(iv) a variety of other practical and translational aspects, including flow separation, flow rates, physiological.

Figure 7 is a schematic representation of the functioning of microphysiological systems. ${ }^{33}$ 


\section{H. Souza, A. C. Massabni}

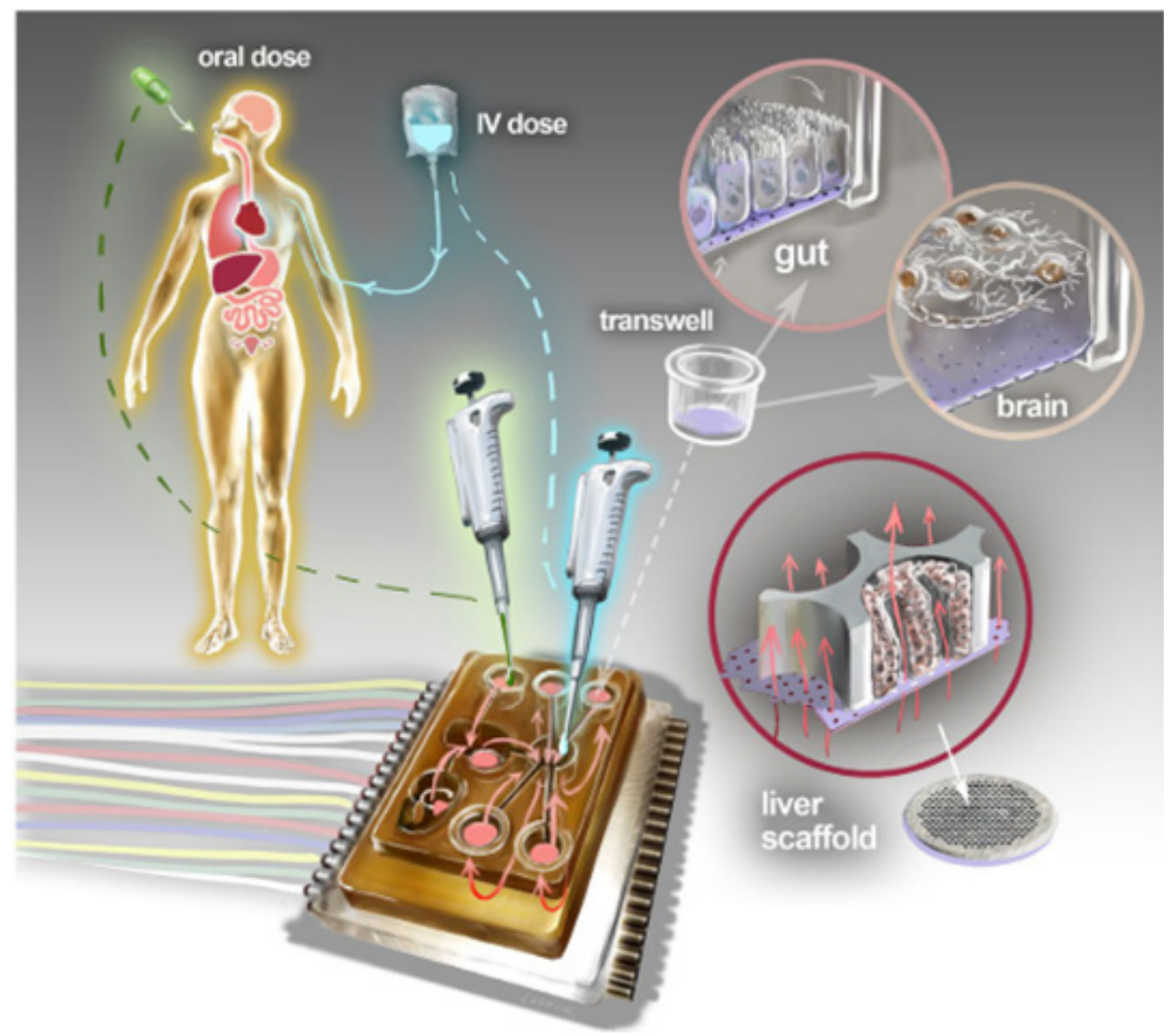

Figure 7 - Schematic representation of the functioning of microphysiological systems applied in pre-clinical pharmacological tests. Source: Edington et al. (2018). Image licensed under a Creative Commons Attribution 4.0 International License.

\section{Conclusions}

Biotechnology has long contributed to the maintenance of human health. From the production of forms for mass immunization, such as vaccines, to the production of revolutionary drugs, such as penicillin, to the production of human insulin for the treatment of diabetes, Biotechnology has enabled an increase in the quality of life of man and helped in the development of the society we know. Even today, biotechnological processes and materials have been developed with the objective of meeting the demand for new products and services to further improve the procedures applied in modern Medicine. The production of scaffolds applied to the regeneration of tissues and organs, induced pluripotent stem cells and microphysiological systems, are just some of the technologies that can further improve Medicine and provide better technologies and therapies for several treatments.

Therefore, the importance of Biotechnology for contemporary society is undeniable, since it would be difficult to progress without the contribution of this important area.

\section{Acknowledgements}

The authors thank Fundação Nacional de Desenvolvimento do Ensino Superior Particular (Funadesp) and Fundação de Amparo à Pesquisa do Estado de São Paulo (Fapesp) Grant n. 2017/11570-3 for financial support.

\section{References}

1. Costa AM, Rosa AJM, Farias Neto AL, Martins CF, Wilches CE, Pereira $C D$, et al. Biotecnologia: estado da arte e aplicações na agropecuária. Planaltina: Embrapa Cerrados; 2011.730 p.

2. Brasil, Ministério do Meio Ambiente (2019). Biotecnologia [Internet].
2019 [cited 13 Dec. 2019]. Available at: https://www.mma.gov.br/ informma/item/7510-biotecnologia.html

3. Brasil, Ministério do Desenvolvimento, Indústria e Comércio Exterior. Fórum de Competitividade de Biotecnologia. Estratégia Nacional de Biotecnologia: Política de Desenvolvimento da Bioindústria. Brasília: CGEE. 2006.

4. Barcelos MC, Lupki FB, Campolina GA, Nelson DL, Molina G. The colors of biotechnology: General overview and developments of white, green and blue areas. FEMS Microbiol Lett. 2018;365(21):111. https://doi.org/10.1093/femsle/fny239

5. Kafarski P. Rainbow code of biotechnology. Chemik. 2012;66(8):8116.

6. Holcberg, I.B., Margalith, P. Alcoholic fermentation by immobilized yeast at high sugar concentrations. European J Appl Microbiol Biotechnol. 1981:13:133-40. https://doi.org/10.1007/BF00703041

7. Martins RA. Contágio: histórias da prevenção das doenças transmissíveis. São Paulo: Editora Moderna; 1997.

8. Rezende JM. À sombra do plátano: crônicas de história da medicina. In Modismos na história da medicina. São Paulo: Unifesp. 2009;137-50. https://doi.org/10.7476/9788561673635.0015

9. Behbehani AM. The smallpox story: Life and death of an old disease. Microbiol Rev. 1983;47(4):455-509. https://doi.org/10.1128/ MMBR.47.4.455-509.1983

10. Fernandes TM. Smallpox immunization in 19th century Brazil: inoc- 
ulation, variolization, vaccine, and revaccination. Hist Cienc Saúde-Manguinhos. 2003;10(2 Suppl):461-74. https://doi.org/10.1590/ S0104-59702003000500002

11. Hilleman MR. Vaccines in historic evolution and perspective: a narrative of vaccine discoveries. Vaccine. 2000;18(15):1436-47. https://doi.org/10.1016/S0264-410X(99)00434-X

12. Medeiros MZ. Vacinas: as origens, a importância e os novos debates sobre seu uso. Fiocruz [Internet]. 2016 [cited 2019 Aug. 21]. Available at: https://www.bio.fiocruz.br/index.php/noticias/1263-vacinas-as-origens-a-importancia-e-os-novos-debates-sobre-seu-uso?showall $=1$

13. Bonanni P, Santos Jl. Vaccine evolution. Perspectives in vaccinology. 2011;1(1):1-24. https://doi.org/10.1016/j.pervac.2011.05.001

14. Larocca LM, Carraro TE. O mundo das vacinas: caminhos (des)conhecidos. Cogitare Enferm. 2000;5(2):43-50

15. Gillray J. The Cow-Pock-or-the Wonderful Effects of the New Inoculation! [photograph]. [London]: The British Museum; 1802. Hand-coloured, etching, $250 \times 355 \mathrm{~mm}$. [cited 13 Dec. 2019]. Available at: https://research.britishmuseum.org/research/collection_ online/collection_object_details.aspx?objectld =1638225\&page=1\&partld =1\&peoA=18459-1-7\&people=18459

16. Mohr Kl. History of antibiotics research. Current Topics in $\mathrm{Mi}$ crobiology and Immunology. 2016;398:237-72. https://doi. org/10.1007/82_2016_499

17. Nossa capa: Alexander Fleming e a descoberta da penicilina. J Bras Patol Med Lab. 2009;45(5):I. https://doi.org/10.1590/S167624442009000500001

18. Guimarães DO, Momesso LS, Pupo MT. Antibiotics: therapeutic importance and perspectives for the discovery and development of new agents. Quím Nova. 2010;33(3):667-79. https://doi. org/10.1590/S0100-40422010000300035

19. Smith RJ, Kahn CR, Jacobson AM, King GL, Weir GC. Joslin: Diabetes melito. 14 ed. Porto Alegre: Artmed; 2009.

20. Pires AC, Chacra AR. Insulin therapy for type 1 diabetes mellitus: past and present. Arq Bras Endocrinol Metab. 2008;52(2):268-78. https://doi.org/10.1590/S0004-27302008000200014

21. Lopes DSA, Pessoa MHN, Santos RS, Barbosa MS. A produção de insulina artificial através da tecnologia do DNA recombinante para o tratamento de diabetes mellitus. Rev Univ Vale Rio Verde. 2012;10(1):234-45

22. Porcellini A. Regenerative Medicine: a review. Rev Bras Hematol Hemoter. 2009;31(2 Suppl):63-6. https://doi.org/10.1590/S151684842009000800017

23. Whitman DH, Berry RL, Green DM. Platelet gel: an autologous alternative to fibrin glue with applications in oral and maxillofacial surgery. J Oral Maxillofac Surg. 1997;55(11):1294-9. https://doi. org/10.1016/S0278-2391(97)90187-7

24. Marx RE, Carlson ER, Eichstaedt RM, Schimmele SR, Strauss JE, Georgeff KR. Platelet-rich plasma: growth factor enhancement for bone grafts. Oral Surg Oral Med Oral Pathol Oral Radiol. $\quad$ 1998;85(6):638-46. https://doi.org/10.1016/\$1079_ 2104(98)90029-4

25. Torgbo S, Sukyai P. Bacterial cellulose-based scaffold materials for bone tissue engineering. Appl Mater Today. 2018;11:34-49. https://doi.org/10.1016/j.apmt.2018.01.004
26. Huang Y, Wang J, Yang F, Shao Y, Zhang X, Dai K. Modification and evaluation of micro-nano structured porous bacterial cellulose scaffold for bone tissue engineering. Mater Sci Eng C. 2017;75:1034-41. https://doi.org/10.1016/j.msec.2017.02.174

27. World Health Organization (WHO). Cardiovascular diseases (CVDS). 2017 [cited 2019 Dec. 11]. Available at: https://www.who.int/en/ news-room/fact-sheets/detail/cardiovascular-diseases-(cvds)

28. Lee SE, Park YS. The role of bacterial cellulose in artificial blood vessels. Mol Cell Toxicol. 2017;13(3):257-61. https://doi. org/10.1007/s13273-017-0028-3

29. Schumann DA, Wippermann J, Klemm DO, Kramer F, Koth D, Kosmehl $\mathrm{H}$, et al. Artificial vascular implants from bacterial cellulose: preliminary results of small arterial substitutes. Cellulose. 2009;16(5):877-85. https://doi.org/10.1007/s10570-0089264-y

30. Takahashi K, Yamanaka S. Induction of pluripotent stem cells from mouse embryonic and adult fibroblast cultures by defined factors. Cell. 2006;126(4):663-76. https://doi.org/10.1016/j. cell.2006.07.024

31. Reis LCJ, Picanço-Castro V, Paes BCMF, Pereira OA, Gyuricza IG, Araújo FT, et al. Induced pluripotent stem cell for the study and treatment of sickle cell anemia. Stem Cells Int. 2017;2017:7492914. https://doi.org/10.1155/2017/7492914

32. Merck Sigma Aldrich. Induced pluripotent stem cell differentiation protocols [Internet]. 2019 [13 Dec. 2019]. Available at: https:// www.sigmaaldrich.com/technical-documents/protocols/biology/ ipsc-differentiation.html

33. Edington CD, Chen, WLK, Geishecker E, Kassis T, Soenksen LR, Bhushan BM, et al. Interconnected microphysiological systems for quantitative biology and pharmacology studies. Scientific Reports. 2018;8(4530):1-18. https://doi.org/10.1038/s41598-01822749-0 